\title{
Applying FABRIC as a Tool to Understanding Architectural and Landscape Icons in a Time of Travel Restrictions
}

\author{
Jacqueline McIntosh (D) and Bruno Marques * (D) \\ Wellington School of Architecture, Te Herenga Waka-Victoria University of Wellington, P.O. Box 600, \\ Wellington 6140, New Zealand; jacqueline.mcintosh@vuw.ac.nz \\ * Correspondence: bruno.marques@vuw.ac.nz; Tel.: +64-4-463-4718
}

Citation: McIntosh, J.; Marques, B. Applying FABRIC as a Tool to Understanding Architectural and Landscape Icons in a Time of Travel Restrictions. Architecture 2021, 1, 99-116. https://doi.org/10.3390/ architecture1020009

Academic Editor: Eckart Lange

Received: 10 September 2021

Accepted: 3 November 2021

Published: 9 November 2021

Publisher's Note: MDPI stays neutral with regard to jurisdictional claims in published maps and institutional affiliations.

Copyright: (c) 2021 by the authors. Licensee MDPI, Basel, Switzerland. This article is an open access article distributed under the terms and conditions of the Creative Commons Attribution (CC BY) license (https:// creativecommons.org/licenses/by/ $4.0 /)$.

\begin{abstract}
Iconic architecture and landscape architecture are most often understood through photographic media that mediates between the idea and the reality for those learning to design. The drastic lockdown responses to COVID-19 and the limitations on local and international travel highlighted the importance of the visual and the potential of the virtual. However, visual media can also be understood as systems that go far beyond a strict representation of an object. In this climate where publicity, politics, and perception play ever more crucial roles, representations of iconic architecture and landscapes increasingly blur the boundaries between the imaginary and the tangible. This paper examines the experience of iconic architecture and landscape in four iconic European cities (Paris, Barcelona, Seville, and Lisbon) as seen through the eyes of fifty postgraduate architecture, interior architecture, and landscape architecture students from New Zealand. It compares their understanding of a building or landscape from its photographic image before engaging with the physical reality. Students were asked to first identify iconic architecture and landscape, then closely analyze and document the essential qualities which established its pre-eminence. A subsequent visit to each of the places provided the opportunity for comparison and the testing of the realities and fictions of the icons themselves. Our research finds that today's architecture students are savvy and sophisticated consumers of technology. It also presents FABRIC (finding, assimilating, being, reflecting, introspecting, and concluding), a conceptual framework that offers additional scaffolding for educating design students through experiential learning in a time of travel restrictions.
\end{abstract}

Keywords: COVID-19; pandemic; iconic; travel restriction; photography; physical object; experiential learning; field trips; architecture; interior architecture; landscape architecture

\section{Introduction}

Throughout history, architectural icons have exemplified the aspirations and values of society. However, in the past few decades, iconic and spectacular architecture and landscape architecture have been used to proliferate and fuel urban economic competition within a globalised culture industry [1]. The term iconic has been defined by two central characteristics [2]. First, it must be famous. Second, it must be imbued with meaning that is both symbolic for a culture and/or a time and is worthy of presenting beautifully what is being represented [1,3]. From an architectural perspective, buildings have been understood to symbolise good taste, power, and status through the attention paid to the identity of the architect [4]. Iconic architects and landscape architects are those who design architecture and landscape architecture that is unique and unreproducible, and which contributes to their global brand expressed in leading cities throughout the world. Julier [5] describes the 'hard branding' of cultural institutions, including new museums, arts complexes, and theatres that are frequently assigned an iconic status. Similarly, Koolhaas observes that shopping is the number one tourist activity, and concludes that retail is the "single most influential force on the shape of the modern city" [6]. In this way, an architectural project can be seen as both a product and a media representing a city, a client, a place, or even 
a real estate product to market [7]. Most recently, with the chaos of a global pandemic, climate change, political outcry, and strained mental health, our relationship with iconic architecture and landscape architecture is undergoing change as it seeks to forge a new language for a society in search of a new identity.

In response to the restrictions imposed by COVID-19 and for architectural education around the globe, the requirements of social distancing and travel restrictions have moved lectures, studio work, presentations, discussions, and final design reviews to virtual classrooms and meeting rooms using various platforms supporting the virtual meeting environment. Virtual site visits are offered as potential replacements for physical experience. This research asks what are the necessary tools to understand architectural and landscape icons in a time of travel restrictions. To understand the implications of virtual site visits, we examine the experience of iconic architecture and landscape architecture in four iconic European cities (Paris, Barcelona, Seville and Lisbon) as seen through the eyes of fifty undergraduate and postgraduate architecture, interior architecture and landscape architecture students from New Zealand. This paper compares their understanding of a building, interior or landscape from its 'virtual' photographic image prior to their visit with their understanding following engagement with the physical reality. It seeks to uncover the scaffolding necessary for experiential learning in a mixed-mode architectural education environment.

\section{Literature Review}

While the term 'iconic' generally signifies a building's particular ability to produce a memorable image, i.e., its 'imageability' [8], such images are usually photographic and part of a series of ephemeral impressions in our digital age in an ever-expanding universe [9]. While the notion of iconicism is comprehensible and straightforward for everyone, for those in the architectural disciplines, including landscape and interior architecture, iconic architecture is more commonly established by its relationship with the photograph and the digital model, where computer visualisation is used to see what is often unseen [10].

Architectural designers use photography in a variety of ways. First, they use it as visual surveying, recording, or documenting to convey as much information on an icon as possible. Second, illustrative photography documents aspects of the icon in a careful artistically composed form. Third, picture photography is employed where the primary concern is to tell the iconic narrative of the object and to get closer to the designer's perception of space [11]. The architectural photograph, by its nature, prioritises sight above all of our other senses. Nevertheless, since the experience of an icon is not limited to vision, photography limits the knowledge of the observer to a single focus due to the choice of angles and framing, which makes that view more apparent and comprehensible at the expense of the entire whole [12,13]. A photograph can be held in the hands of the observer and contemplated in solitude where the viewer is distanced from the subject and independent of place $[14,15]$.

Drawings, photography, and digital technology are essential to establishing the iconic status of buildings, interiors, or landscapes [16]. The drastic lockdown responses to COVID-19 and the limitations on local and international travel eliminated the field trip/excursion/site visit as a learning opportunity and highlighted the importance of the visual. However, these images are anything but 'present', 'corporeal', or three-dimensional (that is, 'iconic' in the word's original sense). Instead, they borrow their iconicity from their ability to multiply infinitely while at the same time retaining their memorability [17]. The power of the image in producing iconicity affects how people give credence to the building and landscapes and, in some cases, the architects they represent. Iconicity works and persists since the buildings, interiors, and landscapes express both symbolic and aesthetic values.

To take a photograph is to decontextualise the object from its physical adjacencies and the societal circumstances in which it is framed $[18,19]$. Buildings, interiors, and landscapes of different scales and types are portrayed side by side in publications, reconfigured in 
new visual relationships, where any meaning that is not inherent in the image itself or in the actions or objects it portrays is lost. In the real world, meanings are defined by the context and the discourse in which they are framed [20,21]. Schumacher, as cited in Sklair, argues "the worst offence of architectural photography, however, is its ability to make terrible buildings look good, photographing a building out of context truly tells a lie'. The images people see of buildings and spaces often do not prepare them for the emotional, in some cases described as spiritual, impact of direct experience. The idea and representation of buildings can be much better than the physical building." [3]. A photograph thereby becomes an interpretation that is never a truly objective description of an icon [15], which leads to the importance of experience for a learning environment.

Much has been written on the importance of experience for student engagement and learning through field trips [22-25]. For those in the architectural disciplines, site visits, excursions and field trips are essential for forming professionals who can respond appropriately when confronted with making places through planning and design. Field trips to significant architecture and landscape architecture also allows students to explore the application of the theoretical principles in practice and meet professionals who can explain their designs and answer questions. Kolb's experiential learning theory supports the belief that learning is a process whereby knowledge is created through the transformation of experience. An important feature of Kolb's theory is that it offers a wide range of experience definitions, from those that involve using our senses, to those that involve abstract thinking using logic and reasoning [26]. Empirical studies support the notion that it is concrete experience that leads to the greatest degree of individual learning [27]. Klein [28] suggests that mere transmission of information does not guarantee reception and that students must be an active party with the information. Experiential learning theories emphasise the importance of the participants learning by doing but then reflecting on the experience $[23,29,30]$. Learning occurs as the participants interact and assimilate new information into that which they already know [31].

One problem with iconic architecture is that the experiences of the building, landscape, interior are often staged by tourism suppliers in such a way that they never obtain an authentic experience. Mehmet et al. [32] found that the dimensions of education and entertainment do not affect satisfaction; however, aesthetics, and escapism do. Pine and Gilmore's [33] model of the four dimensions of experience offers a valuable framework for understanding student preferences. According to them, the richest experiences are those that combine feeling, learning, being, and doing. The outdoor experience allows students to see their landscape/building/interior in context and better understand the associated landscape [34]. Krakowka [24] adopts the Kolb framework to explain the importance of fieldtrips to the teaching of geography, aligning Kolb's four learning stages with four examples for geography. This study suggests that modifying these frameworks can offer a valuable tool for architecture students researching the built environment.

\section{Materials and Methods}

Using an opportunistic sampling method, four iconic European cities (Paris, Barcelona, Seville and Lisbon) were selected due to their ease of access, affordability, and climate (Figure 1). From an International Field Study course, running from November 2019 to February 2020, 50 New Zealand students from architecture (22), landscape architecture (17), and interior architecture (11) participated in this research as part of their study (Figure 2). First, students were asked to research, in groups, the context and culture of each city and then identify iconic architecture and landscapes from the late 20th century to the present (Table 1). Iconic buildings, landscapes, and interiors were identified from recent architectural publications (Platform, ARQ, Mark, Topos, etc.) and websites (such as ArchDaily, Dezeen, Landezine, Land8, etc.). From this list, they each selected one building/landscape/interior from each city. The second assignment involved analysing and documenting the essential qualities that established these buildings/landscapes and interiors pre-eminence (Table 1). Their written analysis served as an information guide, 
which students presented when the building/landscape/interior was visited. As each city was visited, the groups reported on the overall context of the city and its cultural highlights. Groups were divided by discipline and buildings/landscapes/interiors were presented and discussed in situ. The visits provided the opportunity for close analysis as students photographed key elements of the building/landscape/interior and the chance to discuss the importance of authentic context as well as the realities and fictions of the icons themselves. A summary of the student learning process is provided in Figure 3.

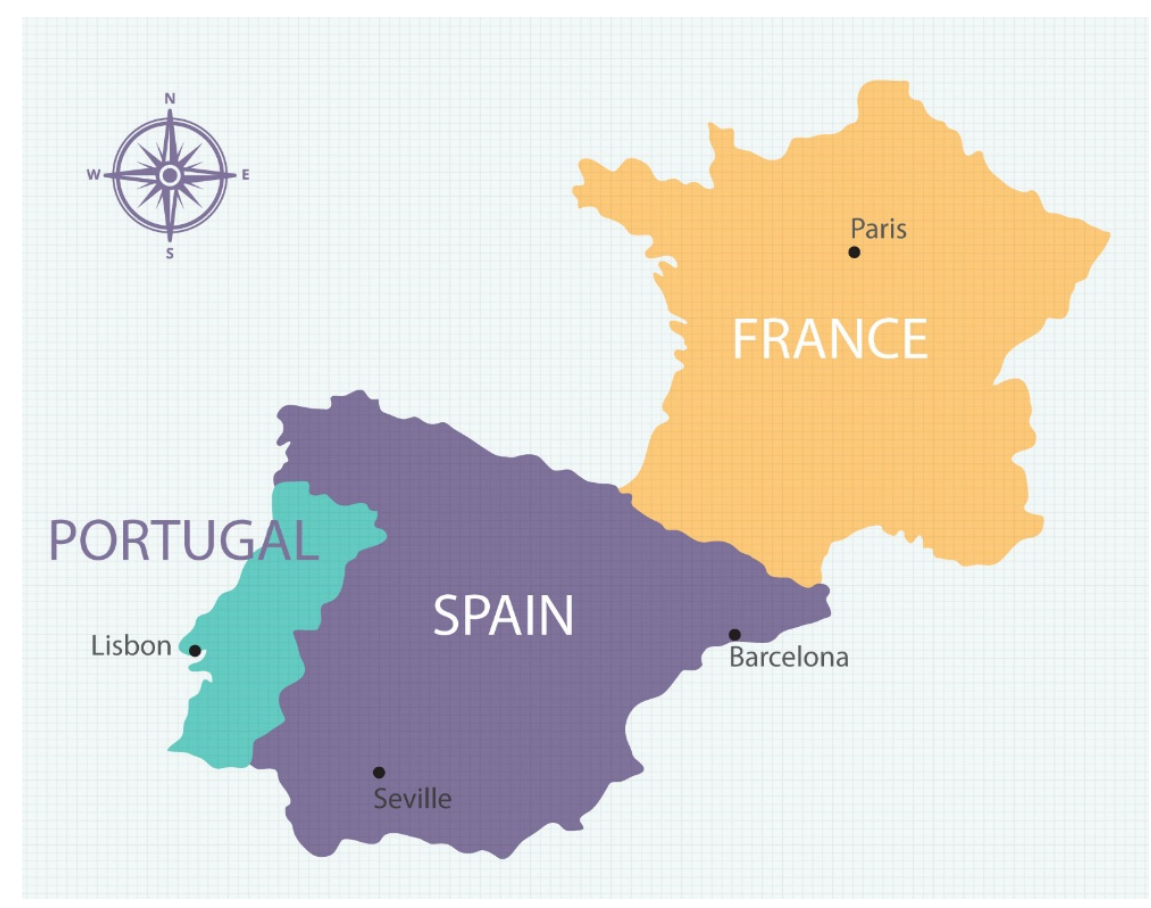

Figure 1. Location of the countries and cities visited.
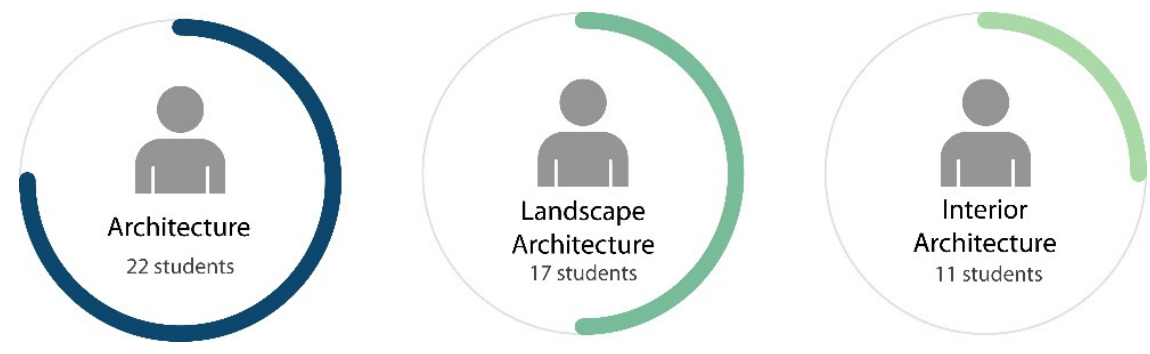

Figure 2. Break-down of student numbers by discipline.

Table 1. Breakdown of assignments.

\begin{tabular}{cccc}
\hline Assignment 1 & Assignment 2 & Assignment 3 & Assignment 4 \\
\hline 15\% of grade & $30 \%$ of grade & $30 \%$ of grade & $25 \%$ of grade \\
Group work & Individual work & Individual work & $\begin{array}{c}\text { Individual work } \\
\text { Context and culture of } \\
\text { each city }\end{array}$ \\
$\begin{array}{c}\text { Analysis and understanding } \\
\text { through photos and drawings }\end{array}$ & $\begin{array}{c}\text { Experiencing the } \\
\text { building/interior/landscape }\end{array}$ & $\begin{array}{c}\text { Final submission, including } \\
\text { reflection and introspection as } \\
\text { well as new design possibilities }\end{array}$ \\
\hline
\end{tabular}

Shortly after introducing and viewing their building/landscape/interior, the presenting student was asked to complete their third assignment, which included an eight-point questionnaire (Tables 1 and 2). The questionnaire asked students to compare their pre-trip research with their actual visit and had to be submitted by the end of the day of the visit 
itself. The questions aimed to capture student's initial reaction, their emotional and physiological response, their experience with others and their overall understanding of the iconic element. Following reflection and introspection, they documented both the tangible and intangible elements of their experience in their final assignment (Table 1). The assignment also identified new possibilities and opportunities for future design and was due four weeks after the field trip was completed.

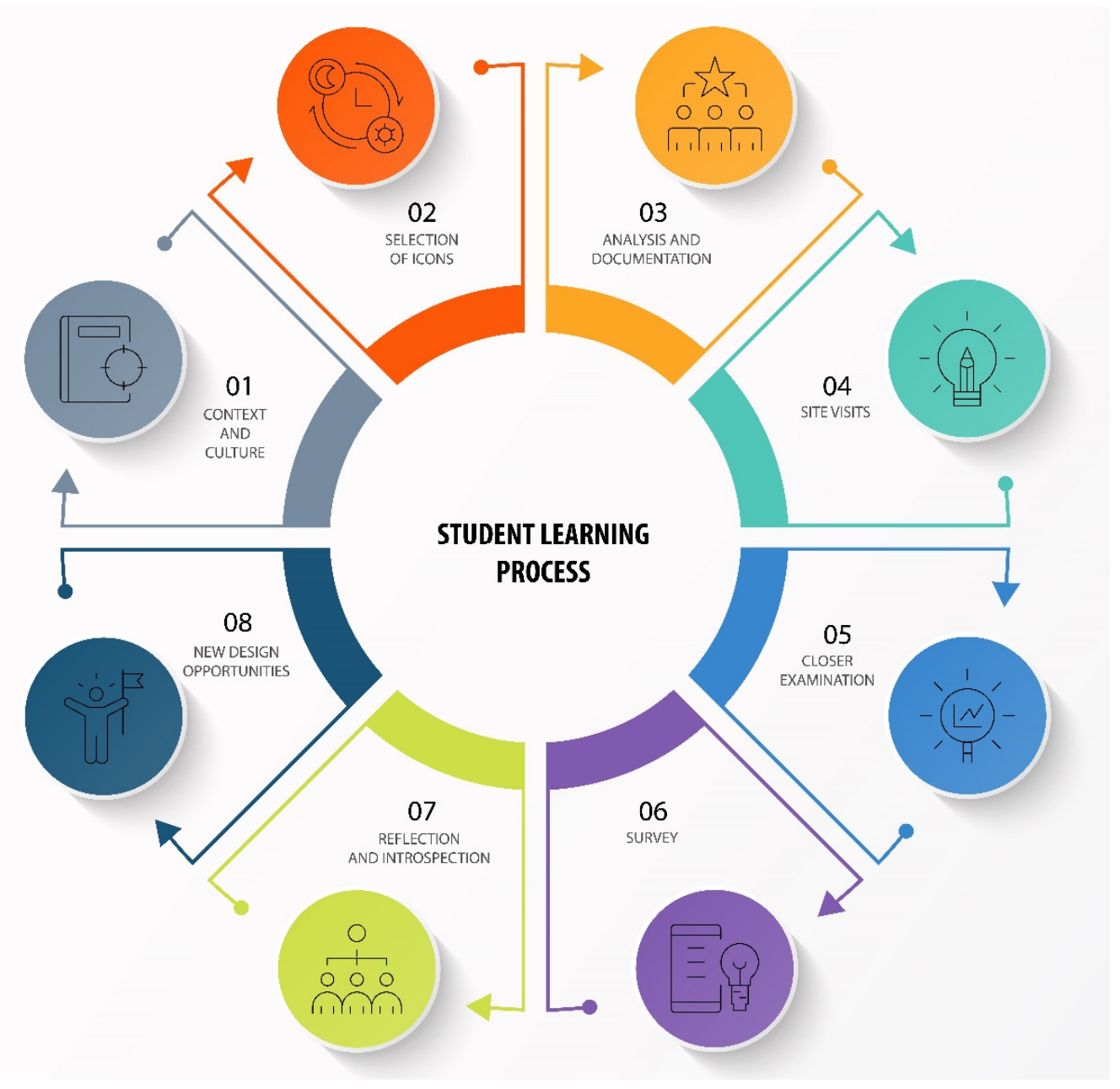

Figure 3. Diagram of the student learning process.

Table 2. Survey questions.

Initial Experience

1. Please describe your experience with your building/interior/landscape?

2. What aspects stand out for you?

3. What were the differences between the real and the photographed?

Effect of emotion and the body

4. How did the experience emotionally affect you?

5. What senses were activated when you visited the site?

6. What bodily changes or states were you aware of at the time?

Influence of the experience of others

7. How were you affected by the experience of others?

New understanding

8. Did your understanding changed after the visit? 
All interviews were transcribed verbatim and analysed using interpretative phenomenological analytic techniques [35,36]. This method permits the researchers to explore and extract meaningful inferences based on personal worlds, emphasising hermeneutics, experience, and in-depth analysis. The IPA coding identifies themes and super-themes while observing context, language used, and content [37,38]. Students and locations were de-identified, then grouped by discipline. From the coding, key themes were extracted adopting an inductive approach and representative quotes were selected, question by question. From the themes generated, the number of comments per theme was calculated and converted into percentages so as to show the significance of the comment. This was then evaluated against the literature to develop a conceptual framework for experiential learning by those designing the built environment.

\section{Results}

The questionnaire focused on comparing the visited icon with the student research, including photography, context, and data. Questions were loosely grouped in four categories: (1) initial reaction to the building, including stand out features and their reflections on the differences between the real and the photograph; (2) reflection and introspection relating to the effect of the building on them, the senses engaged and any bodily changes or states; (3) the influence of the experiences of others; and (4) their conclusions leading to new understandings and knowledge that could be taken into future design work.

Overall, common themes that arose across all answers were scale (big and small), the experience of space, which merges with the idea of embodiment and sensory feeling, and the addition of physiological effects and visual aesthetics (Table 3). The three-way interplay between researching a site from afar, visiting the site, and then photographing it intensified these themes. Unlike other themes, aesthetics was described in both positive and negative ways; students were very detailed about whether their site was beautiful or very unappealing, and these comments have an interesting interaction with optical vision and other senses such as smell, hearing, and touch. Students felt either overwhelming disappointment or intensive satisfaction when visiting the site rather than having a neutral reaction.

Table 3. Student quotes about initial experiences by discipline.

\begin{tabular}{ll}
\hline \multicolumn{1}{c}{ Discipline } & \multicolumn{1}{c}{ Student Comments } \\
\hline Architecture & $\begin{array}{l}\text { "When I arrived at the building, I felt a huge amount of emotion due to the scale of the building. It was powerful } \\
\text { and overwhelming. Walking up the steps took effort and made the journey significant. This gave a feeling of } \\
\text { achievement at the top, helping to reinforce the significance of the arc, celebrating human achievement." }\end{array}$ \\
$\begin{array}{l}\text { "It was apparent that the human scale had not been considered as the site seemed vast and the buildings were } \\
\text { Architecture }\end{array}$ & $\begin{array}{l}\text { overwhelmingly large and towered over us. Overall I would say my experience was underwhelming } \\
\text { and disorienting" }\end{array}$ \\
"Thterior & "The beauty of the undulating gold ceiling is disrupted by a mass of ugly ceiling lights, something that should \\
Architecture & have been considering when the building was being designed."
\end{tabular}

When students were asked to describe their initial experience of their building/landscape/ interior, four main themes emerged: the impact of scale $28.5 \%$, the power of aesthetics / beauty $22.8 \%$, the sense of cohesion $19 \%$ and, finally, the sensory impact $12.3 \%$.

Differences were noted by discipline when reviewing first impression comments (Table 4). For example, comments regarding cohesion/complexity were predominantly made by students from architecture and landscape architecture, whereas interior architecture students were more likely to report on sensory experience. 
Table 4. Examples of disciplinary differences.

\begin{tabular}{ll}
\hline \multicolumn{1}{c}{ Discipline } & \multicolumn{1}{c}{ Student Comments } \\
\hline $\begin{array}{l}\text { Architecture } \\
\text { "... the flow of the gallery was easy to follow and the architect's idea of never having to cross one space more } \\
\text { than once in my opinion was successful and this was the case for me." } \\
\text { Architecture }\end{array}$ & $\begin{array}{l}\text { "The materials used on the ground were textured and interested which drew my eyes to the ground whilst the } \\
\text { slatted metal pergola structure drew my eyes upwards creating a good balance." }\end{array}$ \\
$\begin{array}{l}\text { "Thterior (church) provided a surprisingly warm atmosphere, despite the use of an industrial material palette. The } \\
\text { Architecture }\end{array}$ & $\begin{array}{l}\text { lighting, both ambient and natural was cleverly used to direct the viewer through the space. The design of the } \\
\text { interior spaces was very thoughtfully considered in regards to spatial hierarchy, and how the church would be } \\
\text { inhabited. The detailing of each element was most impressive and made the final design thoroughly coherent." }\end{array}$ \\
\hline
\end{tabular}

When asked to analyse the pre-trip research and photographs against the experience of the visit, student comments could be grouped into four main categories: differences in scale $(39.8 \%)$, complexity in details $(24.2 \%)$ differences in aesthetics/appearance $(18.4 \%)$, and differences related to maintenance (17.4\%). The most significant difference between the studied photographs and the actual building/landscape/interior was that of scale (including interior volume). The spaces were portrayed as either much larger or much smaller than the experience garnered from the visit. Architecture and landscape architecture students made the majority of the comments regarding scale, whereas interior architecture students were more likely to comment on the aesthetics and details (Table 5). A similar question asked what aspects, dimensions, etc., stood out. Here, the impact of the building scale $(32 \%)$ was equal to that of the building details and their complexity $(32 \%)$. Following this was 'other' $(24.3 \%)$, which mainly focussed on elements extraneous to the architecture, followed by lighting (11.5\%).

Table 5. Student quotes comparing expectation to experience by discipline.

\begin{tabular}{ll}
\hline \multicolumn{1}{c}{ Discipline } & \multicolumn{1}{c}{ Student Comments } \\
\hline "The real building was smaller than I had pictured. Perhaps due to the artwork/facade, I had imagined the \\
building on a greater scale. The building in person was far humbler than I had read it in photographs ... . the \\
photographed building could not give a clear understanding of the way the space would feel and operate. This \\
could only be felt by being in the space." \\
"All the photos were from above showing the park standing out in the middle of the surrounding cars. It is an \\
elevated shot, trying to show it as an emerging haven working the centre of bustling streets. In reality, there was \\
no imagery that gave off the ground experience." \\
Architecture \\
$\begin{array}{l}\text { "The photographed building gave the impression that the exterior was completely wrapped with the hexagonal } \\
\text { facade, but in reality, there was really only one feature wall. A major reason they won the design competition } \\
\text { was for the reflective river aspect, however I struggled to see how this was possible due to large trees and the } \\
\text { distance between the building and the river." }\end{array}$
\end{tabular}

Many students found that the visited building/landscape/interior's aesthetic qualities were not easily captured through photography (Table 6).

Table 6. Student comments about the influence of photography by discipline.

\begin{tabular}{ll}
\hline \multicolumn{1}{c}{ Discipline } & \multicolumn{1}{c}{ Student Comments } \\
\hline "The colours are a lot darker than they seem and the building feels a lot more like a massive heavy paperweight \\
than a floating cube. The renders of the building are very deceptive and do not show how the building is \\
actually going to look."
\end{tabular}

Many students were surprised about the change of context from that in the photographs (Table 7). 
Table 7. Student quotes discussing the impact of context by discipline.

\begin{tabular}{|c|c|}
\hline Discipline & Student Comments \\
\hline Architecture & $\begin{array}{l}\text { "The photographs were very similar; however, a lot of the photographs were taken at night when the LED lights } \\
\text { were on projecting images of colour on the facade. I returned to the building at night and found that just like the } \\
\text { mechanical louvres the lights were not working." }\end{array}$ \\
\hline & "The photos showed a clean, manicured design, [but] it was very clear when going to the site that no upkeep \\
\hline Landscape & had been performed over its duration. Small details of damage could be seen such as the colours fading, or \\
\hline Architecture & $\begin{array}{l}\text { being scratched off, as well and weeds had formed in large patches. Although these were minor problems, they } \\
\text { create a dramatic effect that this area was not well looked after, and therefore not cared for by the council." }\end{array}$ \\
\hline $\begin{array}{l}\text { Interior } \\
\text { Architecture }\end{array}$ & $\begin{array}{l}\text { "The images were obviously photoshopped to some extent as ... the exterior colouring was less bold than I had } \\
\text { thought it would be. The interior experience was completely different to the images because of the importance } \\
\text { of how light is used in the spaces, and how it creates a very } 360 \text {-degree experience." }\end{array}$ \\
\hline Architecture & "Almost all photos of the building are of the distinctive roof, where in person the roof can barely be seen." \\
\hline
\end{tabular}

The question of emotional effect is raised when we compare a static image with a piece of architecture or landscape architecture which is experienced by the body (Table 8). Following on from their initial experience, students were then asked to examine the senses that had been activated, namely sight $42.9 \%$, sound $24.8 \%$, touch/haptic $23.7 \%$, and smell $8.4 \%$.

Table 8. Student comments regarding sensory activation by discipline.

\begin{tabular}{|c|c|}
\hline Discipline & Student Comments \\
\hline Architecture & $\begin{array}{l}\text { "Touch and sight were the major senses [engaged] as the walls of the addition seemed to be floating } \ldots \text { at } \\
\text { around hip height and creating intrigue for the user to bend down and peer through the gaps }\end{array}$ \\
\hline & "The design sits on both sides of a main 4-lane road. The pavement [has] large cobbles, so as the cars move \\
\hline Landscape & across it, it is uncomfortable for the car and loud to any pedestrians. However, as you move towards the water's \\
\hline Architecture & $\begin{array}{l}\text { edge of the site, lying down on the steps you become lower than the road and the sound of the cars seems less } \\
\text { noisy and [you hear] the sound of the estuary." }\end{array}$ \\
\hline Interior & "There was a lot of acoustic treatment on the walls which played a huge part in the way we experienced the \\
\hline Architecture & interior. It was almost silent which was interesting considering bathrooms are thought to be loud." \\
\hline Architecture & "The mossy smell of the wetland surrounding the building gave the experience a natural touch." \\
\hline $\begin{array}{l}\text { Landscape } \\
\text { Architecture }\end{array}$ & "The sea air was fresh and salty and added to the experience, reminding you of its location." \\
\hline
\end{tabular}

Certain elements stood out for students, dominating their initial experience. In particular, elements that could only be captured by the close investigation possible in a site visit (Table 9).

Table 9. Student comments regarding outstanding elements by discipline.

\begin{tabular}{ll}
\hline \multicolumn{1}{c}{ Discipline } & \multicolumn{1}{c}{ Student Comments } \\
\hline Architecture & $\begin{array}{l}\text { "A small design detail that had huge impact was the black mirrored ceiling feature over top of the most delicate } \\
\text { mosaic tiles, the mirror allows the public to view and inspect the tiles without disturbing them." }\end{array}$ \\
$\begin{array}{l}\text { "There was a strong disconnection between the size of the plaza and the size of the buildings ... . The vast plaza } \\
\text { Architecture }\end{array}$ & $\begin{array}{l}\text { also removes any sense of the human scale in the design, making people feel lost and unsure of what they } \\
\text { should be doing in the site." } \\
\text { "The way in which the facade created different images from different angles stood out as an interesting part of } \\
\text { the building. Up close the texture of the pre-cast panels resemble QR codes which read as texture from a } \\
\text { distance This is interesting as the primary message-the themes of overwhelming information and technology } \\
\text { (up close panels) and the way they affect us, and we as human interact with them (far away)." }\end{array}$ \\
\end{tabular}

A secondary question asked about awareness of bodily changes or states, which was followed by a question regarding the emotional impact of the building/landscape/interior (Table 10). The first question posed some problems for the students, most (33.3\%) reported on temperature or their emotional response $(21 \%)$, and feelings such as excitement, or calmness/relaxation and their sensory experience $(5 \%)$. 
Table 10. Student experiences of bodily changes by discipline.

\begin{tabular}{cl}
\hline Discipline & \multicolumn{1}{c}{ Student Comments } \\
\hline Architecture & $\begin{array}{l}\text { "I noticed that the rooms facing the sun were incredibly hot and actually didn't feel as small as they had } \\
\text { appeared in images. The central auditorium however was a cool, comfortable temperature and quite calming. } \\
\text { The entire building was much warmer than outside." } \\
\text { "The only bodily change that I was aware of when visiting my building was a sense of calmness which in my } \\
\text { opinion is a result of the appropriate scale, proportions, colour and lighting creating a peaceful mood." }\end{array}$ \\
\hline
\end{tabular}

Finally, when asked how the experience emotionally affected the students there were mixed emotions, $43.5 \%$ of the students had an overall positive experience, while $56.5 \%$ felt disappointment when confronted with the reality (Table 11).

Table 11. Student quotes about emotional impact by discipline.

\begin{tabular}{ll}
\hline \multicolumn{1}{c}{ Discipline } & \multicolumn{1}{c}{ Student Comments } \\
\hline Architecture & $\begin{array}{l}\text { "I felt excited and intrigued and was pleasantly surprised in the crisp, cleanliness I felt within the building. } \\
\text { Crisp white usually feels clinical or sanitary, however with the clean finishing, irregular windows, shadows, } \\
\text { perforations and forms I felt like I was in a piece of art" }\end{array}$ \\
$\begin{array}{l}\text { "The transition as you enter the park from the urban area was refreshing and made me slow down and enjoy the } \\
\text { space. From walking through densely urbanised areas to suddenly be enclosed by such lush vegetation was } \\
\text { Architecture }\end{array}$ & $\begin{array}{l}\text { really overwhelming and could imagine this to be a place of reflection or retreat from urban life" } \\
\text { "I was in awe of the building. It was incredibly beautiful and made me think about how craftsmanship is so }\end{array}$ \\
$\begin{array}{l}\text { Architecture } \\
\text { lacking in architecture today." }\end{array}$ \\
$\begin{array}{l}\text { Interior } \\
\text { Architecture }\end{array}$ & $\begin{array}{l}\text { "I was expecting to feel somewhat upset by such a drastic design change from the surrounding classical beauty } \\
\text { than I expected. I was surprisingly impressed by the building." }\end{array}$ \\
\hline
\end{tabular}

COVID requirements for social distancing and the experience of visiting a building/landscape/interior with others can affect the experience of place and space. Students were asked about how the experience of others impacted their own experience. Four themes emerged from the analysis: enhanced enjoyment (38.1\%), developed understanding $(36.8 \%)$, distraction $(15.7 \%)$, and other $(9.2 \%)$. Of these, $75 \%$ of students felt that the presence of similar others enhanced their experience of the icon through a shared emotional experience, followed by a sharing of intellectual ideas. Negative experiences were associated with either disinterest by colleagues, by the distraction of other tourists, or a difference of opinion (Table 12).

Table 12. Student comments about the impact of others on their experience by discipline.

\begin{tabular}{|c|c|}
\hline Discipline & Student Comments \\
\hline Architecture & $\begin{array}{l}\text { "Everyone else was in awe as it was their first time seeing the building, there was a sense of urgency to explore } \\
\text { which made the design more exciting ... being amongst so many eager photographers inspired me to put in a } \\
\text { large effort into the photography ... The others who were with me seemed to share my enthusiasm for the } \\
\text { design, making the entire journey more exciting and intriguing." }\end{array}$ \\
\hline $\begin{array}{l}\text { Landscape } \\
\text { Architecture }\end{array}$ & $\begin{array}{l}\text { "Discovering the different elements, you were drawn to the excitement of others as they found new things to } \\
\text { play with ... it was almost contagious." }\end{array}$ \\
\hline $\begin{array}{l}\text { Interior } \\
\text { Architecture }\end{array}$ & "The 'wow' reactions continued through everyone as new aspects were found and shared with each other." \\
\hline
\end{tabular}

Once the initial excitement wore off and students started to engage with the components of the architecture, the group experience heightened their understanding (Table 13). 
Table 13. Student evaluative comments after group discussion by discipline.

\begin{tabular}{ll}
\hline \multicolumn{1}{c}{ Discipline } & \multicolumn{1}{c}{ Student Comments } \\
\hline "The group made me more excited but also much more critical than if I had been by myself through their \\
questions and comments .. Others provoked me to notice things I wouldn't have otherwise such as the feel of \\
some materials and carefully thought construction details."
\end{tabular}

However, not all experiences with a group were positive (Table 14).

Table 14. Student quotes regarding negative aspects of others by discipline.

\begin{tabular}{ll}
\hline \multicolumn{1}{c}{ Discipline } & \multicolumn{1}{c}{ Student Comments } \\
\hline Architecture & "The tourists were annoying as they interfered so much, but they will always be there so it cannot be helped." \\
$\begin{array}{l}\text { Landscape } \\
\text { Architecture }\end{array}$ & $\begin{array}{l}\text { design more worrying about my surroundings but when finding areas that people were no longer there, I was } \\
\text { able to appreciate the design more." }\end{array}$ \\
\hline
\end{tabular}

When asked if their understanding of the building/interior/landscape changed after their visit, the students overwhelmingly $(80.5 \%)$ reported a change from what they had gleaned from photographs (Table 15).

Table 15. Student comments about changes of understanding by discipline.

\begin{tabular}{|c|c|}
\hline Discipline & Student Comments \\
\hline Architecture & $\begin{array}{l}\text { "Yes. Through images, one cannot truly get the feeling or understanding of weightlessness that the building } \\
\text { creates in its interior." }\end{array}$ \\
\hline $\begin{array}{l}\text { Landscape } \\
\text { Architecture }\end{array}$ & $\begin{array}{l}\text { "I didn't expect the spaces to flow so well together considering the diversity of detail, palette and spatial } \\
\text { configuration." }\end{array}$ \\
\hline Architecture & $\begin{array}{l}\text { "The genius of the acoustics (such as the perfection of the main auditorium and the sound isolation through the } \\
\text { opposing corrugations of the glass) was absolutely incredible." }\end{array}$ \\
\hline Landscape & "The connection between built and natural was so seamless that it seemed the vegetation was inside the \\
\hline Architecture & building even though it was its reflection." \\
\hline Interior & "Visiting the site allowed me to gain an understanding of the changing atmosphere. This is due to the use of \\
\hline Architecture & both ambient and natural light, and the way that lighting has been thoughtfully placed." \\
\hline
\end{tabular}

Students also learned how photographs can lie (Table 16).

Table 16. Student comments about the dangers of learning from photographs by discipline.

\begin{tabular}{ll}
\hline \multicolumn{1}{c}{ Discipline } & \multicolumn{1}{c}{ Student Comments } \\
\hline Architecture & $\begin{array}{l}\text { "The photographs produce an understanding that this is a very large space. But in reality, it's not. The courtyard } \\
\text { has created this effect. The circular ceramic tubes held by a steel structure covering the entire courtyard creates a } \\
\text { visual illusion of a larger space than in reality. This has been done well in efforts to enlarge the site." } \\
\text { "Many of the photos used to showcase the site were aerial to show the best angle of the design. For this reason, I } \\
\text { failed to realise the lack of consideration given to detail and components at the human scale. The aerial images } \\
\text { showed a holistically structured and well considered design whereas the actual experience of the site consisted } \\
\text { of a lot of spaces called gardens that are very odd and contain random, unidentifiable elements and half of the } \\
\text { site is concealed behind large buildings so you are constantly getting lost in the vastness of the site." } \\
\text { Architecture } \\
\text { "My understanding of lighting changed. I learned a few more techniques to use with lighting to create } \\
\text { aterior }\end{array}$ \\
Architecture & atmosphere and different effects."
\end{tabular}




\section{Discussion}

The primary sources of information in architecture schools come from online resources, which contain visual images and picture-dominated books and periodicals. COVID imperatives for staying at home, combined with the closure of libraries, bookstores, and government offices, limited information gathering to online sources, where images are tampered with through fragmented, cropped, framed and touched up versions of the buildings/interiors and landscapes (Figure 4). For these reasons, teaching context, including how cities use icons for branding, is particularly crucial. Students need to understand the limitations of their sources and why architectural images may be deliberately misrepresented. As the context is laden with meaning, knowledge of the global setting also needs to be acknowledged in current times of globalisation. Contextualising, or FINDING, is an essential first step for architecture, interior architecture, and landscape architecture students. This is an additional step to that proposed by Kolb [23] and modified by Krakowka [24].

\section{LIFE IN LISBON}
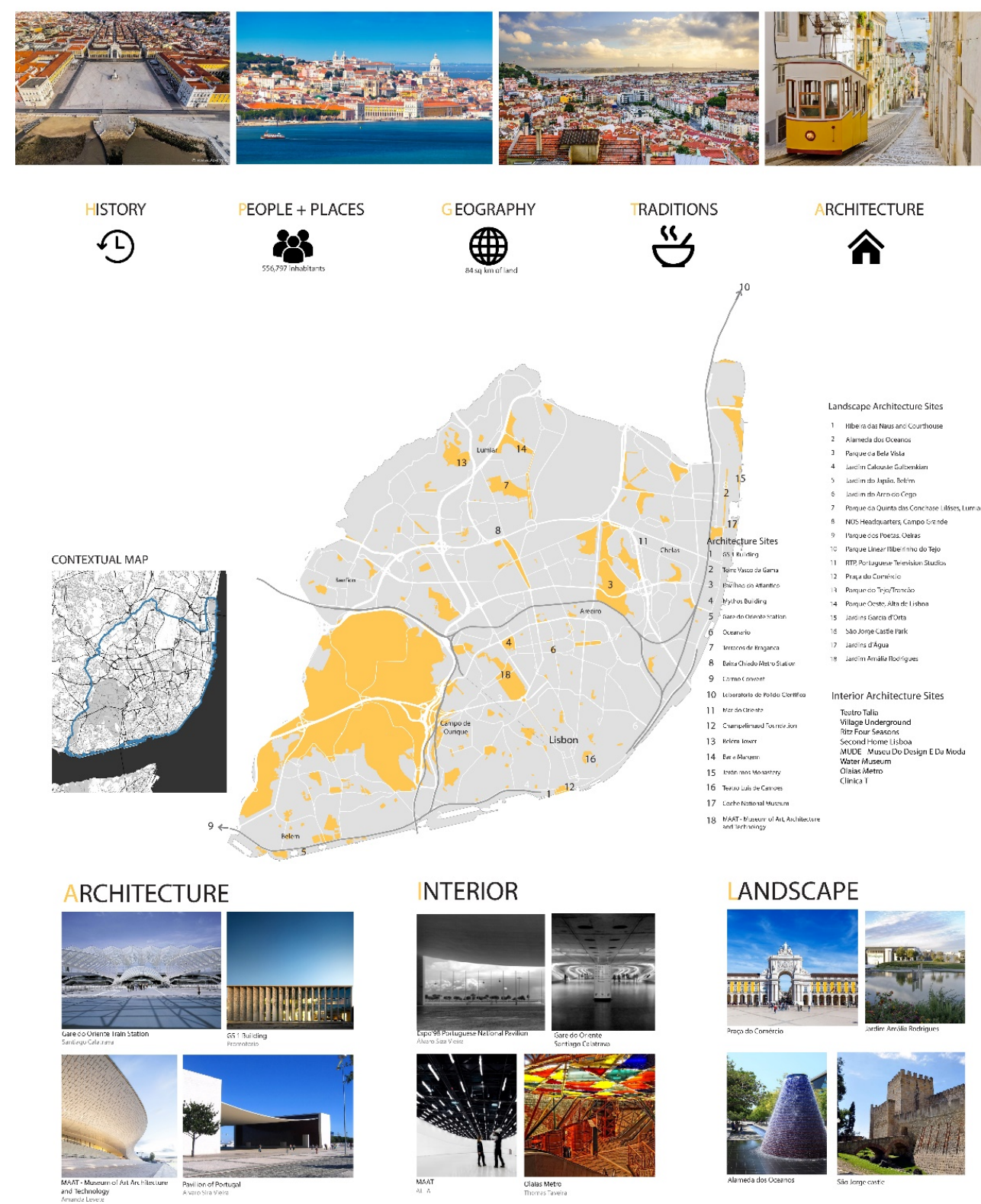

Figure 4. Example of student work produced in the first step (Finding) of the FABRIC framework. 
Once students understood the implications of context, they then had to examine the range of 'potential' iconic buildings/landscapes/interiors to identify those worthy of further investigation (Figure 5). Krakowka [24] proposes planning as the first step of understanding, wherein, for geography this involves looking at maps, researching the area of the field trip, planning the route, etc., and for Kolb [23] it is active experimentation. At this stage, much valuable information can be obtained from online resources. Aerial photography, building and interior images and plans can provide much detail about a building and show overlooked, invisible or inaccessible parts. This investigation process aligns with traditional delivery, which is primarily in a lecture or studio format supplemented with online investigation. ASSIMILATING information at this stage is important in order for students to complete their initial assessment which then they will compare to the 'real' during the site visit. This step also provides a sense of anticipation, thereby engaging with emotion.
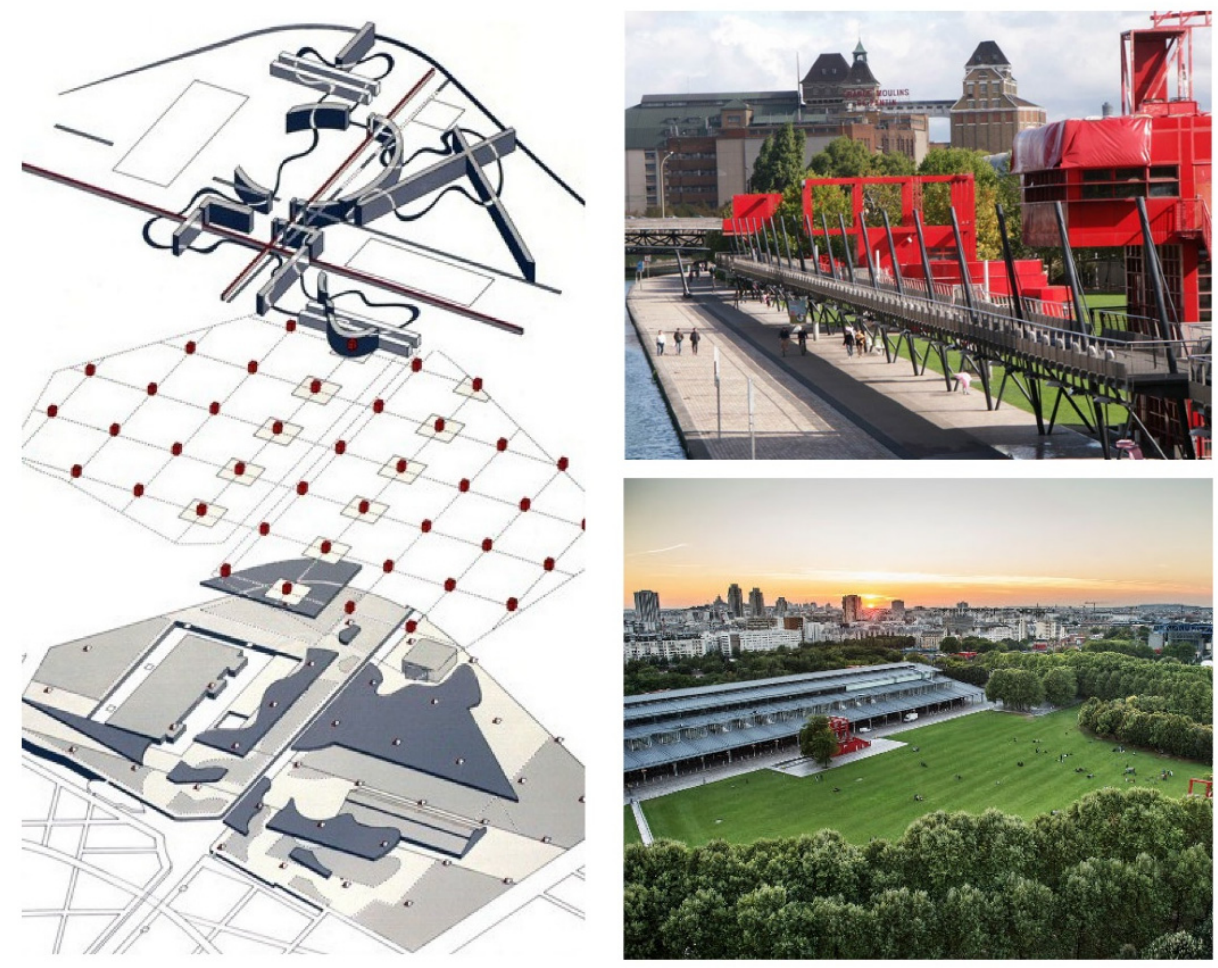

Figure 5. Example of student work produced in the second step (Assimilating) of the FABRIC framework.

While some education activities were successfully replaced virtually during the COVID-19 pandemic, many activities were affected by the measures taken to limit the spread of the disease. Community events, exhibitions, and activities were cancelled or postponed. Site visits and field trips were not possible and their virtual replacement often encountered constraints, with access to equipment and the difficulty in collecting on-site material to prepare a virtual tour [39]. This eliminated the opportunity for physically BEING in the space. Studying space physically benefits multi-sensory experience, thus increasing the understanding of the way space is arranged. This critical step of experiential learning aligns with 'concrete experience' as noted by Kolb and 'DO' as modified by Krakowka.

Without the physical experience of architecture, it is easy to underestimate the extent of this deficiency for our perception and understanding [40]. Students found that either the building, interior or landscape in question did not perform to the image built up or read from the photographs, or that the building, interior or landscape added no more to the experience that the photograph gave (Tables 3 and 11). While many would expect a photograph to be a 'virtual twin' of the physical building/interior/landscape, the incidences of 
digital alterations to enhance desirability, the curated selection of photographic images to show only selected spaces, and the ageing of the building/interior/landscape over time, all contributed to the lack of authenticity.

"The prettier lies - the greater the seduction - the essential narrowing of architecture to an image may be part of its eternal hopeless political promise' ... "High profile buildings become a laboratory of invested meaning and naturally disappointment." [41]

Many of our students experienced the feeling of arriving at a building, interior or landscape, well known or not and being disappointed (Table 17).

Table 17. Student quotes by discipline.

\begin{tabular}{cl}
\hline \multicolumn{1}{c}{ Discipline } & \multicolumn{1}{c}{ Student Comments } \\
\hline Architecture & $\begin{array}{l}\text { "After I saw the real building, I felt rather disappointed. It's an extraordinary site and the architecture doesn't } \\
\text { complement it. The architecture hides the site instead of showcasing it." } \\
\text { "The surrounding buildings had brighter colours and were very joyous and interesting, but the park itself made } \\
\text { Landscape } \\
\text { Architecture feel alone and unwanted in the site. While the original idea was to create a space that celebrated the } \\
\text { separation from the city, the actual site made the pedestrian feel unwanted and discarded." }\end{array}$ \\
\hline
\end{tabular}

Our research found that when students visited their building/interior/landscape, they were now able to effectively 'receive' the information gathered as they compared their expectations with their experience. This action of thinking profoundly and reflectively is directly aligned with Step 3 from Kolb and Krakowka's frameworks.

Our students engaged with internalised critical theory REFLECTING on their buildings (Figure 6). Much of the learning experience was heightened by being physically located in the space, promoting social encounters and active participation of body and senses [42]. Students reported that scale, complexity, aesthetics, and sensory experience deepened the engagement with the physical icon. Moreover, the scale was reported as the most significant difference in the experience of the icon through photography when compared with the real experience. Scale is the projective size of a place relative to the human body and plays an important role when experiencing a place [43]. It is through scale that people perceive the relationships between objects, and establish a mind-map that defines the way in which their body acts.

For landscape architecture students, issues related to climate and temperature were mentioned as the most predominant difference. For example, landscape architecture students visited the sites in late autumn/early winter, while most photographs represented sites in optimal summer conditions. The temporal difference in experience between the real and the photograph directly affects the experience of a place and its vegetation. This difference did not affect students in architecture or interior architecture in the same way. For landscape architecture students, it is through the spatial and climatic conditions of a place that social desires and emotions are conditioned [44].

Next, INTROSPECTING involved the close examination of emotional response, the experience of buildings/landscapes/interiors and the abstraction of intangible concepts, themes and ideas. Many have theorised about the importance of introspection and phenomenology and have suggested that if architecture or landscape architecture is predicated on a bodily experience, we are in the realm of 'atmosphere' [17,45-48]. Recalling the experience of immersion in architectural space is deemed to disturb or even inhibit its perception as an image [17]. Regarding Kolb and Krakowka's frameworks, this step (Introspecting) is labelled as Abstract Conceptualisation (Kolb) or THINK (Krakowka). However, while aligned with Kolb, it is separate from the definition of THINK (Krakowka), which is of particular importance for design students.

A final step for our architecture students was CONCLUDING, to end their examination of the iconic object and consider how their understanding of architecture, interior architecture and landscape architecture had changed and how they might then take what they had learned into future design. This is an additional step to Kolb and Krakowka. On 
completion, architecture students are expected to use their experience to develop new ideas and apply this critical thinking process within the context of producing a well-reasoned architectural project [49]. With foundations in experiential learning, these processes provide evidence that real-world experiences can offer opportunities to test, trial, revise and develop a student's subject knowledge. Direct experience was a crucial component of their understanding.
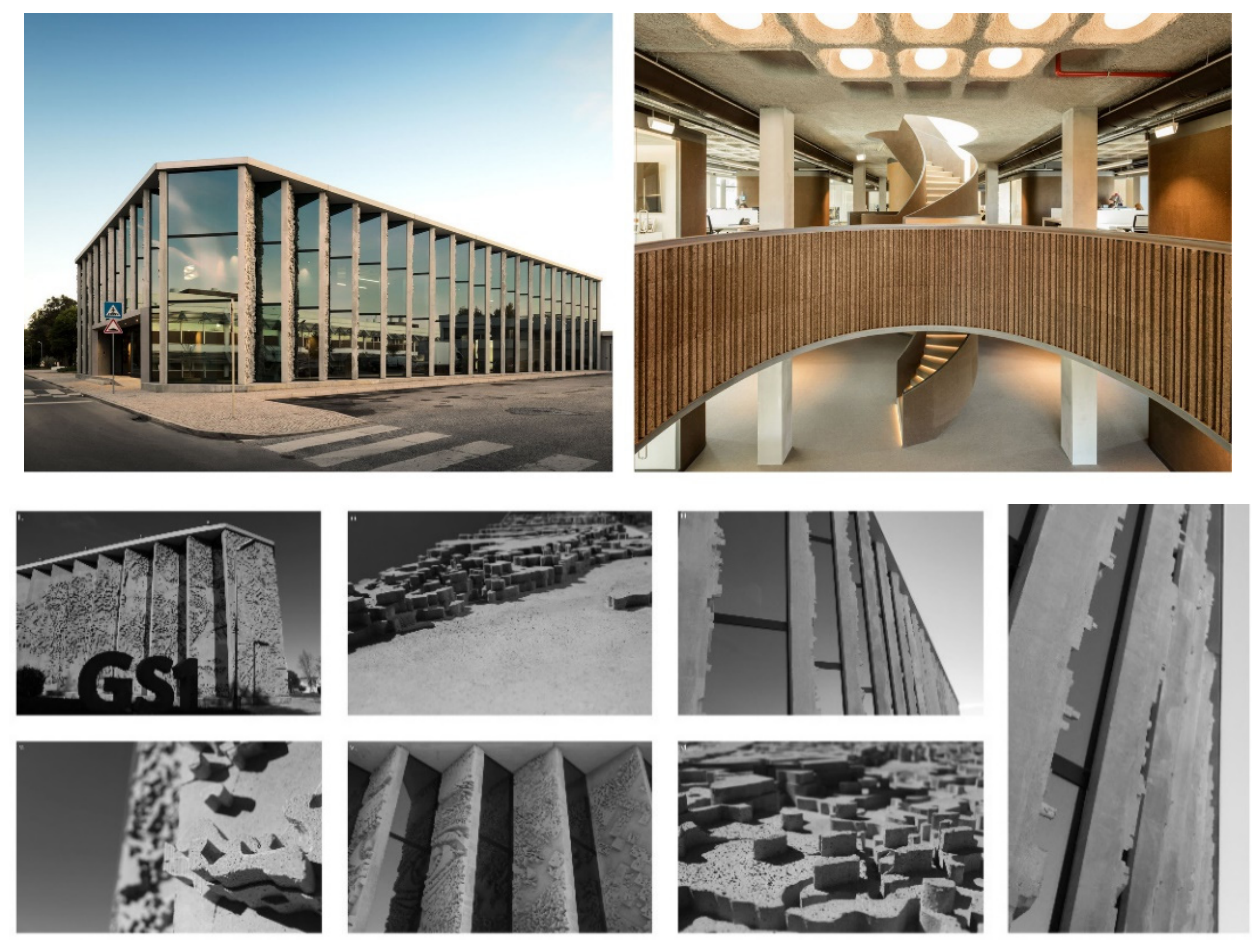

Figure 6. Published photographs compared with student work and reflection (reflecting) of the FABRIC framework.

The activities associated with field trips permit students to engage with the core fabric of buildings, interiors and landscapes and understand the tangible and intangible values that form such fabric. The staged process allowed students to reflect on the values that underpin an experience and associate those with ideas, places and themes. In addition, such experience and emotional response allowed students to fully comprehend the design output and extrapolate concepts and ideas into a coherent design framework for future use. FABRIC (finding, assimilating, being, reflecting, introspecting, and concluding) can provide a framework for enhanced experiential learning for those in the architecture professions, containing both tangible and intangible values (Table 18).

The potential long-term impact of the pandemic on architecture, landscape architecture, and interior architecture is the subject of ongoing discussion [50]. Many new tools and techniques have been developed and adopted for teaching online and there is an ongoing development of virtual technologies to try to augment the loss due to restrictions on site visits, etc. Virtual field trips have been found to solve many of the issues associated with taking students on excursions, such as the cost, the unsustainability of travel, and the disruption to student course schedules [48-53]. Further, advocates of virtual field trips point out the advantages of engagement from reviewers, critics, and jurors from across the country and from abroad [39].

Virtual travel can take students to places that would not be possible in person - hey can go beyond reality [32]. As with photography, advanced technologies can give advanced results including sharper colours, better lighting performance, changes to scale, not to mention increased aesthetic pleasure and seduction, all of which can lead to illusionary results and the potential to serve a broader agenda. For these reasons, the experience of 
physical space is still essential for architectural education. It is still impossible to match the experience of walking as a means for understanding a place and engaging with its smells, feel, and atmosphere, which are all impossible to replicate authentically.

Table 18. FABRIC Conceptual Framework (adapted from $[23,24])$.

\begin{tabular}{|c|c|c|c|}
\hline Kolb & Krakowka & Proposed Conceptual Framework & Student Comments \\
\hline & & $\begin{array}{l}\text { FINDING } \\
\text { Understanding the context, overcoming tacit } \\
\text { knowledge of place }\end{array}$ & \\
\hline $\begin{array}{l}\text { Active } \\
\text { Experimentation }\end{array}$ & $\begin{array}{l}\text { PLAN } \\
\text { Looking at maps, researching the, } \\
\text { planning the route }\end{array}$ & $\begin{array}{l}\text { ASSIMILATING } \\
\text { Selecting the icon and researching it }\end{array}$ & \\
\hline & & BEING & \\
\hline $\begin{array}{l}\text { Concrete } \\
\text { Experience }\end{array}$ & $\begin{array}{l}\text { DO } \\
\text { The field trip }\end{array}$ & $\begin{array}{l}\text { Acting, discovering the site for the first time. } \\
\text { Visit the icon and experience it. It also } \\
\text { includes the experience of relating and } \\
\text { associating ideas, places, and themes. }\end{array}$ & $\begin{array}{l}\text { See Tables 3, 5, } 10 \\
\text { and } 14\end{array}$ \\
\hline $\begin{array}{l}\text { Reflective } \\
\text { Observation }\end{array}$ & $\begin{array}{l}\text { OBSERVE } \\
\text { Reflecting on the field trip and } \\
\text { what was discovered }\end{array}$ & $\begin{array}{l}\text { The action of thinking profoundly and } \\
\text { reflecting on the experiences and what was } \\
\text { discovered during the field trip. }\end{array}$ & $\begin{array}{l}\text { See Tables } 4,6,9 \\
\text { and } 13\end{array}$ \\
\hline \multirow[t]{2}{*}{$\begin{array}{l}\text { Abstract } \\
\text { Conceptualisation }\end{array}$} & $\begin{array}{l}\text { THINK } \\
\text { Using what was experienced in a } \\
\text { geographical framework. } \\
\text { Applying what was experienced } \\
\text { to learned concepts }\end{array}$ & $\begin{array}{l}\text { INTROSPECTING } \\
\text { The examination of one's emotional response } \\
\text { and experience of } \\
\text { buildings/landscapes/interiors and use that } \\
\text { to abstract out concepts, themes and ideas } \\
\text { into a coherent design framework } \\
\text { CONCLUDING }\end{array}$ & $\begin{array}{l}\text { See Tables } 7,8,11,12 \\
\text { and } 17\end{array}$ \\
\hline & & $\begin{array}{l}\text { Applying found knowledge in a new } \\
\text { design setting }\end{array}$ & See Tables 15 and 16 \\
\hline
\end{tabular}

The second outcome of travel restriction has been an increase in domestic tourism. The restrictions on international travel have resulted in the substitution of international tourists with domestic ones, which means that people are increasingly visiting tier-two cities and searching for local icons of architecture and landscape architecture. Students enjoy field trips, collaboration, and group comradery that help crystallise connections between theory and reality and contribute to enhanced learning. As the density of iconography is reduced in rural or semi-rural settings, more time is available for exploration and a more profound overall experience. These spaces and places are available to students for direct experience, and they also have the added potential of extrapolation. Combining the direct experience of the local with techniques for understanding the global icon can optimise learning outcomes. Emerging questions relate to how architecture should then be evaluated, which forces an interrogation of the word 'iconic'.

\section{Conclusions}

Iconic architecture, interior architecture, and landscape architecture are most often understood through photographic media that mediate between the idea and the reality for those learning to design. The drastic lockdown responses to COVID-19 and the limitations on local and international travel highlighted the importance of the visual and the potential of the virtual in understanding architecture. A close examination of iconicity also highlights its relationship to capitalist interests and demonstrates how the visual media can also be understood as a system that goes far beyond a strict representation of the object. In a climate of 'post truth' where publicity, politics and perception play ever more crucial roles, and representations of iconic architecture and landscapes increasingly blur the boundaries between the imaginary and the tangible. 
This research compared the image of iconic architecture and landscape in four iconic European cities (Paris, Barcelona, Seville and Lisbon) with the physical experience as seen through the eyes of fifty undergraduate and postgraduate architecture, interior architecture and landscape architecture students from New Zealand. It finds that today's students are savvy and sophisticated consumers of technology and that with appropriate scaffolding, a meaningful alternative experience of buildings, interiors, and landscapes can be provided. For example, students were able to access research in foreign languages using translation software, construct 3D models based on 2D datasets, understand context based on GIS (geographical information systems) modelling of solar, wind and water impacts, and identify photoshopped images. FABRIC is proposed as a conceptual framework for educating design students through experiential learning in times of travel restriction. "We cannot allow ourselves to return to a pre-pandemic 'normality' and continue to build the same type of buildings or teach the same syllabi or instruct classes with the same teaching goals." [54]. By adopting the FABRIC framework, local architecture can be used as a model for understanding international icons through the overarching themes of scale, the experience of space, embodiment and sensory feeling, and visual aesthetics. While "architectural photography is just product photography as no picture can ever successfully emulate the real and truly representation and experience of architecture" [55], the use of this framework can help overcome the potential risks for those in design disciplines, which have been exacerbated through virtual travel in the face of travel restrictions.

We find that an expanded framework for experiential learning is necessary for students researching the built environment, particularly one that emphasises the importance of context, clearly separates the action of reflection from that of introspection, and concludes with applying lessons learned in ongoing creative work. These steps form useful strategies for extending students' capabilities in thinking creatively as well as developing their confidence. In the face of globalisation, where iconic architecture is a significant part of the contemporary city, its image, and its identity, regional contexts for iconic architecture are replaced by global contexts. Our research also foreshadows a renewed interest in the local and more sub-urban centres for ease of access, for the slowing of experience, and greater 'authenticity'. A new attention to regionalism can create and sustain identity, considering a more local contextual harmony that represents and respects the character of that place. By using FABRIC as a tool to understanding architecture, interior architecture and landscape directly in their local built environment, students not only learn about how to understand the virtual experience of icons, but they gain a greater sense of stewardship and appreciation for their local 'place', one that can foster a heightened responsibility for their surroundings.

Author Contributions: Conceptualization, J.M. and B.M.; methodology, J.M. and B.M.; formal analysis, J.M. and B.M.; investigation, J.M. and B.M.; data curation, J.M. and B.M.; writing-original draft preparation, J.M. and B.M.; writing-review and editing, J.M. and B.M. All authors have read and agreed to the published version of the manuscript.

Funding: This research received no external funding.

Institutional Review Board Statement: The study was approved by the Human Ethics Committee of Te Herenga Waka - Victoria University of Wellington and conducted within their ethical guidelines (protocol code 0000020280).

Informed Consent Statement: Informed consent was obtained from all subjects involved in the study.

Data Availability Statement: Data presented in this study are available on request from the corresponding author. The data are not publicly available due to ethical and privacy restrictions.

Conflicts of Interest: The authors declare no conflict of interest. 


\section{References}

1. Sklair, L. Iconic architecture and urban, national, and global identities. In Cities and Sovereignty: Identity Politics in Urban Spaces; Davis, D., Duren, N., Eds.; Indiana University Press: Bloomington, IN, USA, 2011; pp. 179-195, ISBN 978-0-253-00506-9.

2. Sklair, L. Iconic architecture in globalizing cities. Int. Crit. Thought 2012, 2, 349-361. [CrossRef]

3. Sklair, L. The Icon Project: Architecture, Cities, and Capitalist Globalization; Oxford University Press: New York, NY, USA, 2017; ISBN 978-0-19-046418-9.

4. Berg, P.O.; Kreiner, K. Corporate architecture: Turning physical settings into symbolic resources. In Symbols and Artifacts: Views of the Corporate Landscape; Gagliardi, P., Ed.; de Gruyter: Berlin, Germany, 1990; pp. 41-67, ISBN 978-0-202-30428-1.

5. Julier, G. Urban Designscapes and the Production of Aesthetic Consent. Urban Stud. 2005, 42, 869-887. [CrossRef]

6. Barreneche, R.A. New Retail; Phaidon Press: New York, NY, USA, 2008; ISBN 978-0-7148-4862-4.

7. Ponzini, D. The Values of Starchitecture: Commodification of Architectural Design in Contemporary Cities. Organ. Aesthet. 2014, 3, 10-18.

8. Lynch, K. The Image of the City; Harvard-MIT Joint Center for Urban Studies Series; Harvard University Press: Cambridge, MA, USA, 1960; ISBN 978-0-262-62001-7.

9. Warnaby, G. Rethinking the Visual Communication of the Place Brand: A Contemporary Role for Chorography? In Rethinking Place Branding; Kavaratzis, M., Warnaby, G., Ashworth, G.J., Eds.; Springer International Publishing: Cham, Switzerland, 2015; pp. 175-190, ISBN 978-3-319-12423-0.

10. Brott, S. The iconic and the critical. In Global Perspectives on Critical Architecture; Hartoonian, G., Ed.; Routledge: Oxfordshire, UK, 2016; pp. 137-150, ISBN 1-315-58496-4.

11. De Maré, E.S. Photography and Architecture; Praeger: Westport, CT, USA, 1961.

12. Marques, B.; McIntosh, J. The Spell of the Visual and the Experience of the Sensory: Understanding Icons in the Built Environment. Charrette 2018, 5, 68-77.

13. Downes, M.; Lange, E. What You See Is Not Always What You Get: A Qualitative, Comparative Analysis of Ex Ante Visualizations with Ex Post Photography of Landscape and Architectural Projects. Landsc. Urban Plan. 2015, 142, 136-146. [CrossRef]

14. Colomina, B. Le Corbusier and Photography. Assemblage 1987, 4, 6-23. [CrossRef]

15. Willocks, V. The Image of Architecture: Architectural Photography. In Research Paper; Victoria University of Wellington: Auckland, New Zealand, 1993.

16. Hyun, M.S.; Bafna, S. The Photographic Expression of Architectural Character: Lessons from Ezra Stoller's Architectural Photography. J. Archit. 2019, 24, 778-802. [CrossRef]

17. Stierli, M. Architecture and Visual Culture: Some Remarks on an Ongoing Debate. J. Vis. Cult. 2016, 15, 311-316. [CrossRef]

18. Nassauer, J.I. Framing the Landscape in Photographic Simulationt. J. Environ. Manag. 1983, 17, 1-6.

19. Lange, E. The Limits of Realism: Perceptions of Virtual Landscapes. Landsc. Urban Plan. 2001, 54, 163-182. [CrossRef]

20. Meethan, K. Introduction: Narratives of Place and Self. In Tourism, Consumption and Representation: Narratives of Place and Self; Meethan, K., Anderson, A., Miles, S., Eds.; CABI: Oxfordshire, UK, 2006; pp. 1-23. ISBN 1-84593-164-5.

21. Soberg, M. Theorizing the Image of Architecture: Thomas Ruff's Photographs of the Buildings of Mies van Der Rohe. In Proceedings of the 2008 Conference Architectural Inquiries, Gothenburg, Sweden, 25 April 2008; Chalmers University of Technology: Gothenburg, Sweden, 2008; pp. 1-10.

22. DeWitt, J.; Storksdieck, M. A Short Review of School Field Trips: Key Findings from the Past and Implications for the Future. Visit. Stud. 2008, 11, 181-197. [CrossRef]

23. Kolb, D.A. Experiential Learning: Experience as the Source of Learning and Development; Pearson Education: Upper Saddle River, NJ, USA, 1984; ISBN 978-0-13-295261-3.

24. Krakowka, A.R. Field Trips as Valuable Learning Experiences in Geography Courses. J. Geogr. 2012, 111, 236-244. [CrossRef]

25. Radder, L.; Han, X. An Examination Of The Museum Experience Based On Pine And Gilmore's Experience Economy Realms. JABR 2015, 31, 455. [CrossRef]

26. Healey, M.; Jenkins, A. Kolb's Experiential Learning Theory and Its Application in Geography in Higher Education. J. Geogr. 2000, 99, 185-195. [CrossRef]

27. Cassady, J.C.; Kozlowski, A.; Kornmann, M. Electronic Field Trips as Interactive Learning Events: Promoting Student Learning at a Distance. J. Interact. Learn. Res. 2008, 19, 439-454.

28. Klein, P. Active Learning Strategies and Assessment in World Geography Classes. J. Geogr. 2003, 102, 146-157. [CrossRef]

29. Cornell, R.M.; Johnson, C.B.; Schwartz, W.C., Jr. Enhancing Student Experiential Learning with Structured Interviews. J. Educ. Bus. 2013, 88, 136-146. [CrossRef]

30. Jose, S.; Patrick, P.G.; Moseley, C. Experiential Learning Theory: The Importance of Outdoor Classrooms in Environmental Education. Int. J. Sci. Educ. Part B 2017, 7, 269-284. [CrossRef]

31. Ernst, C.M.; Buddle, C.M.; Soluk, L. The Value of Introducing Natural History Field Research into Undergraduate Curricula: A Case Study. Biosci. Educ. 2014, 1-12. [CrossRef]

32. Mehmet, K.; Kukul, V.; Çakir, R. Conceptions and Misconceptions of Instructors Pertaining to Their Roles and Competencies in Distance Education: A Qualitative Case Study. Particip. Educ. Res. 2018, 5, 67-79.

33. Pine, B.J.; Gilmore, J.H. The Experience Economy: Work Is Theatre \& Every Business a Stage; Goods \& Services are No Longer Enough; Harvard Business School Press: Boston, MA, USA, 1999; ISBN 978-0-87584-819-8. 
34. Thompson, J.J.; Conaway, E.; Dolan, E.L. Undergraduate Students' Development of Social, Cultural, and Human Capital in a Networked Research Experience. Cult. Stud. Sci. Educ. 2016, 11, 959-990. [CrossRef]

35. Smith, J.A.; Jarman, M.; Osborn, M. Doing Interpretative Phenomenological Analysis. In Qualitative Health Psychology: Theories and Methods; Behaviour and Health Series; Murray, M., Chamberlain, K., Eds.; SAGE Publications: Thousand Oaks, CA, USA, 1999; pp. 218-240, ISBN 978-0-7619-5661-7.

36. Smith, J.A.; Flowers, P.; Larkin, M. Interpretative Phenomenological Analysis: Theory, Method and Research; SAGE Publications: London, UK, 2009; ISBN 978-1-4462-4325-1.

37. Attride-Stirling, J. Thematic Networks: An Analytic Tool for Qualitative Research. Qual. Res. 2001, 1, 385-405. [CrossRef]

38. Braun, V.; Clarke, V. Using Thematic Analysis in Psychology. Qual. Res. Psychol. 2006, 3, 77-101. [CrossRef]

39. Klippel, A.; Zhao, J.; Oprean, D.; Wallgrün, J.O.; Chang, J.S.-K. Research Framework for Immersive Virtual Field Trips; IEEE: Osaka, Japan, 2019; pp. 1612-1617.

40. Jones, P.B. The Photo-dependent, the Photogenic and the Unphotographable: How our Understanding of the Modern Movement has been Conditioned by Photography. In Camera Constructs: Photography, Architecture and the Modern City; Higgott, A., Wray, T., Eds.; Routledge: London, UK, 2016; pp. 69-82, ISBN 1-315-26092-1.

41. Connah, R. How Architecture Got Its Hump; Preston Thomas Memorial Lecture Series; Department of Architecture, C.U., Ithaca, New York, Ed.; MIT Press: Cambridge, MA, USA, 2001; ISBN 978-0-262-53188-7.

42. Marques, B.; Freeman, C.; Carter, L.; Pedersen Zari, M. Sense of Place and Belonging in Developing Culturally Appropriate Therapeutic Environments: A Review. Societies 2020, 10, 83. [CrossRef]

43. Montello, D.R. A New Framework for Understanding the Acquisition of Spatial Knowledge in Large-Scale Environments. Spat. Temporal Reason. Geogr. Inf. Syst. 1998, 143-154.

44. Kristianova, K.; Joklova, V. Education by Research in Urban Design Studio. In Proceedings of the EDULEARN17 9th International Conference on Education and New Learning Technologies, Barcelona, Spain, 3-5 July 2017; International Academy of Technology, Education and Development (IATED): Barcelona, Spain, 2017; pp. 2691-2694.

45. Böhme, G.; Thibaud, J.-P. The Aesthetics of Atmospheres; Routledge: London, UK, 2016; ISBN 1-315-53818-0.

46. Petrović, E.K.; Marques, B.; Perkins, N.; Marriage, G. Phenomenology in Spatial Design Disciplines: Could it Offer a Bridge to Sustainability? In Advancements in the Philosophy of Design; Vermaas, P.E., Vial, S., Eds.; Design Research Foundations; Springer International Publishing: Cham, Switzerland, 2018; pp. 285-316, ISBN 978-3-319-73301-2.

47. Sloterdijk, P. Mobilization of the Planet from the Spirit of Self-Intensification. Drama Rev. 2006, 50, 36-43. [CrossRef]

48. Zumthor, P. Atmosphères, Environnements Architecturaux-Ce Qui m'entoure; Birkhäuser: Basel, Switzerland, 2008; ISBN 978-3-7643-8841-6.

49. Marques, B.; McIntosh, J.; Campays, P. Creative Design Studios: Converting Vulnerability into Creative Intensity. Int. J. Innov. Educ. 2021, 7, 1-20. [CrossRef]

50. Architecture Deans on How COVID-19 Will Impact Architecture Education. 2020. Archinect. Available online: https:// archinect.com/features/article/150195369/architecture-deans-on-how-covid-19-will-impact-architecture-education (accessed on 17 July 2021).

51. Jaselskis, E.J.; Jahren, C.T.; Jewell, P.G.; Floyd, E.; Becker, T.C. Virtual Construction Project Field Trips Using Remote Classroom Technology; Ruwanpura, J., Mohamed, Y., Lee, S.-H., Eds.; American Society of Civil Engineers: Banff, AB, Canada, 2010; pp. 236-245.

52. Klemm, E.B.; Tuthill, G. Virtual Field Trips: Best Practices. Int. J. Instr. Media 2003, 30, 177.

53. Tuthill, G.; Klemm, E.B. Virtual Field Trips: Alternatives to Actual Field Trips. Int. J. Instr. Media 2002, $29,453$.

54. Papu, S.; Pal, S. Braced for Impact: Architectural Praxis in a Post-Pandemic Society. Available online: https://advance. sagepub.com/articles/preprint/Braced_for_Impact_Architectural_Praxis_in_a_Post-Pandemic_Society/12196959 (accessed on 6 January 2021).

55. Bergera, I. Photography and Modern Architecture in Spain: Focusing the Gaze. In Proceedings of the Photography and Modern Architecture Conference Proceedings, Porto, Portugal, 22-24 April 2015; Trevisan, A., Maia, M.H., Moreira, C.M., Eds.; University of Porto: Porto, Portugal, 2015; pp. 30-43. 